\title{
Swiss Humanitarian Aid in Spain and Southern France through Paul Senn's camera (1937-1942)
}

\author{
Natascha Schmöller \\ The National Distance Education University (U.N.E.D.) \\ e-mail: denanesh@yahoo.com \\ ORCID iD: http://orcid.org/0000-0001-8165-1988
}

Submitted: 18 May 2018. Accepted: 1 April 2019

\begin{abstract}
The aim of this article is to provide a brief biography of the Swiss photographer Paul Senn, and through the analysis of his photographic journalism resulting from his trips to Spain from 1937 to 1939, add a nuance from the visual perspective of the Civil War and Swiss humanitarian aid for the victims in situ. His photography kept track of both the Republican victims during "La Retirada" as well as of the refugees from Nazism in the South of France during 1942. His aim was to document the historical facts for Swiss readers, potential donors and affiliates of humanitarian aid. The final caption of a published photograph reinforces the compositional resources that Paul Senn employed to foster empathy with the homeless.
\end{abstract}

KEYWORDS: Paul Senn; Swiss aid; Zürcher Illustrierte; Photograph.

Citation / Cómo citar este artículo: Schmöller, Natascha (2019) "Swiss Humanitarian Aid in Spain and Southern France through Paul Senn's camera (1937-1942)". Culture \& History Digital Journal, 8 (2): e020. https://doi.org/10.3989/ chdj. 2019.020

RESUMEN: La ayuda humanitaria suiza en España y el Sur de Francia a través de la cámara de Paul Senn (19371942).- El objetivo de este artículo consiste en aportar una breve biografía del fotógrafo suizo Paul Senn, y por medio del análisis de su periodismo fotográfico resultante de sus viajes a España de 1937 a 1939, añadir un matiz desde la perspectiva visual de la Guerra Civil y de la ayuda humanitaria suiza para los damnificados in situ. Su fotografía siguió el rastro tanto de las víctimas republicanas durante la Retirada como de estas y de los refugiados del nazismo en el sur de Francia a lo largo del año 1942, con el objetivo de documentar los hechos históricos para los lectores suizos, posibles donantes y afiliados de la labor humanitaria. El comentario final de una imagen publicada incide en los recursos compositivos que Paul Senn aplicó para fomentar la empatía con los desamparados.

PALABRAS CLAVE: Paul Senn; Ayuda Suiza; Zürcher Illustrierte; Fotografía.

Copyright: (C) 2019 CSIC. This is an open-access article distributed under the terms of the Creative Commons Attribution 4.0 International (CC BY 4.0) License. 


\section{THE PHOTOJOURNALIST PAUL SENN}

The Swiss Paul Senn (August 14, 1901 Rothrist April 25, 1953), of humble and peasant origins, after completing his apprenticeship as a cartoonist, advertising retoucher and his experience as designer in Switzerland, Italy, France, Germany, Belgium, Spain and England, worked as an image editor in Basler Nachrichten and as a permanent collaborator of the Zürcher Illustrierte, (ZI), a pioneering magazine in offering ambitious reports compiled with graphic criteria and documented with images until its closure in $1941 .^{1}$

His photographic reports explored all sorts of topics, above all general, social and every day. Although the cooperation with Zürcher Illustrierte was crucial for Paul Senn, he also worked for 40 other newspapers and magazines, including Schweizer Illustrierte Zeitung and the magazine Sie und Er. For the latter, he wrote the texts. His social sensibility was reflected in his work as a national photographer, his documentary images of Swiss peasants and trade unionists in the thirties, the juvenile reformatories, the Waldau psychiatric clinic, the Thorberg prison or the documentary about the "Verdingkinder" project. ${ }^{2}$ In 1944 he published together with the journalist Peter Sura$\mathrm{va}^{3}$ a pioneering article on the sexual abuse suffered by a young man from Berne within his foster family.

With regard to his international activity, after his first trip to Spain in 1933 to visit Pablo Casals, Senn accompanied the Swiss humanitarian aid convoy to Spain in 1937 during the Civil War and participated in "La Retirada" through Le Perthus in 1939, documenting these experiences with camera and words. In 1942 he followed the fate of Spanish and Jewish refugees in Southern France in Récébédou, Rivesaltes, Elne and Banyuls, both in internment camps and in the Swiss humanitarian aid centres. His cosmopolitan attitude was further reflected in his participation in a project involving exhumation of French partisans massacred by the Nazis, his impressions of post-war reconstruction and his interest in photographing Swiss emigrants in the USA, as well as in his images of artists and musicians. He also experimented with colour photography in the forties.

\section{IN SPAIN (1937 AND 1939) ACCOMPANYING SWISS HUMANITARIAN AID ${ }^{4}$}

The photographer was part of a convoy of the SAS (Schweizerische Arbeitsgemeinschaft für Spanienkinder), known in Spain as "Ayuda Suiza" (Swiss Aid). In 1937 during his trips from Marseilles to Valencia he witnessed and suffered the bombardments and had to battle to obtain photographic paper. The SAS had started its philanthropic aid project in and for Spain. Through its trucks, named after illustrious and heroic personalities of Swiss and universal history: Nansen, Wilson, Dunant, Pestaloz$z i$, Dufour and the coach Zwingli, this latter financed by the initiatives of Swiss children at Sunday school; they started to transport food donated from Switzerland to Spain. The trucks had been designed by volunteer assis- tant Karl Ketterer with folding benches for multiple uses. During his mission in Spain, Ketterer participated in the trips these trucks made between Madrid and Valencia to evacuate the population of Madrid from the Francoist and Italian bombing. On the outward journey from Madrid, the people had a seat on the bench, whilst on the way back, the possibility of folding the benches against the walls of the truck made it easier to transport food and fruit for the besieged population of Madrid.

After mentioning in his reports various measures for defence and protection of the civilian population against the aerial attacks and bombings in Valencia, such as the blackout and the removal of superfluous clutter in homes, which could become obstacles in critical situations, Paul Senn came to the following scathing conclusion: "Only if, along with the blackout and clearance of junk/furniture from attics, there is a "de-blackout" [term invented by Paul Senn] and a removal of junk from the brains and minds of the large masses of the population, can one expect reason sometimes to prevail. Then the dawn of humanity will break ${ }^{5}$ "

Paul Senn joined a trip to Madrid by the road called during the Civil War the "main radial road from Madrid to Castellón via Valencia" built by Primo de Rivera and with a length of about 380 kilometres, which for a truck meant a journey of 8 to 9 hours. It was the main artery for evacuations and transportation of food on account of its access to the sea. This fast, heavy traffic resulted in several accidents in various vehicles, documented by the journalist's photographs. He portrayed a courier messenger of the Republican government about whom he comments:

A courier messenger on the way. With alarming speed these mechanized messengers, on their wheel motor vehicles of powerful engine drive between Valencia and Madrid, sometimes from 10 to 12 together, sometimes alone. They carry important documents from the Directorate for War Operations in Madrid to the Government in Valencia and vice versa. ${ }^{6}$

His next photographic portrait was the military hospital in Valencia where many maimed or legless soldiers, including Russian aviators, German volunteers, as well as Spanish fighters, agreed to be immortalized by the photographer who, in turn, expressed his envy the doctors, since they focused solely and exclusively on the real fact of wresting lives from death, without having to reflect on the meaning and causes of war.

Immediately afterwards, he visited the Republican Government shelter on García de Paredes Street in Madrid. This transit shelter, (before the war a convent in function), became a place of action for Swiss humanitarian aid and a starting point for evacuations. Here, the people who were willing to move, and who had spent the night there, were waiting for the Swiss truck that would take them to Valencia. Before they had been given the opportunity to bathe, had received clothes donated by the Swiss civilian population and had been vaccinated. The 
staff, a total of 40 people, included about ten nurses, including Irma Schneider, future wife of Rodolfo Olgiati, general director of Swiss Relief, whom Paul Senn portrayed with a Spanish child, in addition to documenting the long waiting hours of the victims, eating and resting, alongside their few personal belongings.

The SAS carried out the evacuations with two of their trucks that undertook trips in all directions, three times a week. The roofs of the vehicles, as protection against the possible air attacks, carried the cross of the Swiss flag painted or as extended canvas, which served to prevent pilots from regarding them as targets for their bombs. When they no longer had supplies from Switzerland, they loaded food from the Ministry of Agriculture from the Valencia area to take it to Madrid. They also transported the donations for the displaced rural population, consisting of onions, oranges, lemons and rice. (Olgiati, Rodolfo, 1944: 39).

He also sent to Switzerland a faithful reflection of the effects of the bombings in Valencia and Madrid: demolished and crumbling buildings. These photographs, with an essentially informative purpose, lack from the emotional impact generated by his portraits of the displaced.

\section{PHOTO REPORTS IN SUPPORT OF VICTIMS (1939, 1942)}

No less dramatic is the photographic testimony of "La Retirada" through Le Perthus from January 28, 1939 after the fall of Barcelona, reflected in the Der Aufstieg magazine. The article that accompanies Paul Senn's photographic material strongly condemns the non-intervention of the great democracies and the indifference to the tragedy of the Civil War in Spain, except for the underlying economic interests that are disguised as apparently benevolent actions in favour of the peoples of the world.

Another article in the magazine ZI, written by Paul Senn himself, includes the following data and significant facts: On January 28, 15,000 people crossed the border through Le Perthus. Men who were subject to republican military service were prevented from crossing, and the refugees' domestic animals (cats, dogs, sheep, poultry) were slaughtered on the very border. ${ }^{7}$ Regarding the population that fled, his explanatory comment was: "They arrived with no money, no passport, some by car, but mostly on foot, with a bundle of belongings and poorly dressed. It was not possible to carry out an accurate control of each one. ${ }^{8}$

The impressions coincide with the report sent by Ruth von Wild, SAS voluntary helper in Spain, in which she described the atmosphere of panic of the Catalan civilian population after the rumour was spread on the $23^{\text {rd }}$ of January that the Republican Government had moved to Figueras. The general reaction, including that of Swiss Aid, was mass flight. Together with Children's Aid, they gathered a total of 82 children from the Swiss colonies in Catalonia - García Lorca and Granja de Teija - and crossed the border on January, 30 travelling in the Dunant, and Dufour trucks and the Whippet vehicle. In her journey, which started on the $25^{\text {th }}$ of January, Ruth described lootings in the Children's Aid warehouses in Barcelona that contained about 60 tonnes of food. She also mentioned the imminent threat of the crowd willing to attack and take advantage of any occasion to seize goods in the food stores on the $26^{\text {th }}$ of January, following the rumour that the Republican Government, prior to departure, had ordered the closure of all warehouses. While waiting at La Jonquera on way to Le Perthus, Ruth witnessed the following:

What we had not perceived in the darkness in its full magnitude, now we were shown with cruel clarity as in a cinematographic film: that is to say thousands and thousands of pedestrians moving towards the border as the pole of salvation with the only thought: "Only to leave Spain, then our misery will come to end", bunched together from head to head, pushed, pressed, waved up and down; the hundreds of crashed cars and trucks that lay alongside the road; the abandoned trolleys broken into pieces, stray animals without an owner; the children who cried and did not understand this misfortune together with their desperate mothers; the road covered centimetre-thick with rubbish, mattresses, wool blankets, papers and waste, and traffic police, operating unsuccessfully against all of this. ${ }^{9}$

Paul Senn documented with his photography the arrival in France of a Spanish peasant sitting on a pavement on French soil, allegory of the exodus of a people:

The peasant crossed the border; he is now on French soil. There is some milk available, thanks to the French humanitarian aid organization for basic needs, but there are no mugs. A rusty tin, thrown away by tourists and collected from the nearest ditch, serves as drinking glass. ${ }^{10}$

After his reports related to the Civil War, Paul Senn returned to the South of France after a stay in the US, and other reports linked to the Second World War.

Paul Senn made a 30-day trip beginning on January 3, 1942 from Geneva to Toulouse, headquarters of Swiss humanitarian aid in Southern France where he obtained relevant information about Swiss Relief. From there he continued on to Récébédou, Rivesaltes, Elne as far as Banyuls s.-M, documenting the fate of Spanish refugees, but also that of the Jewish victims in the concentration camps. He also photographed the different Swiss Relief action centres in Southern France. The impressions of this trip were compiled in issue No. 9 of the Schweizer Illustrierte Zeitung magazine of 25 February 1942 by means of the said photographic report.

At the doors of the headquarters in Toulouse, the centre of Swiss humanitarian aid in the South of France, Paul Senn took pictures of two or three class representatives of an academic year who every fortnight collected their corresponding ration of dried fruits and nuts and milk powder for the 30 children of the class they represented. The photographer's camera also immortalized the director of an establishment for the deaf-mutes in Toulouse when 
distributing food that was part of the portion for his 70 protégés provided in a trolley by humanitarian aid. Fundamental too was the image of the director, Maurice Dubois, standing in his distribution warehouse amidst numerous boxes of supplies.

Paul Senn's visit to the camp of Récébédou camp was captured in a touching photograph of two gaunt old inmates, one of them stooped over, both equipped with empty tins, moving towards the Swiss helper Lydia Fournier to receive their powdered milk. The dichotomy between the victims' misery and the health of the Swiss is blurred thanks to the dialogue and the visible appreciation between the three.

Extremely dramatic is the visual narration of the Rivesaltes concentration camp where Paul Senn coincided with Friedel Reiter, who had built a Swiss barrack with Elsa Lüthi-Ruth, intended for the care of interned children and food distribution. The neatness of its façade and the decorative mural with Swiss motifs was in stark contrast with the sad camp barracks. This barrack was protected by a pitched roof, and inside it was the canteen, the store, the kitchen, a small living room, a small office and a closet. Thanks to these provisions, around 400 undernourished people could receive additional rations. Paul Senn's main motif were the faces of the malnourished children in Rivesaltes, whose disconcerting gaze had to challenge the Swiss reader, both in each individual portrait and when standing in the queue waiting for the milk to be delivered. These children, who, according to the description, had lost the child's innate capability to laugh, had to transmit by means of their own photograph the terrible situation in the camp, since censorship impeded explicit descriptions.

In the maternity in Elne several nurses were portrayed, like the matron Anna Bucher de Brig, the Spanish refugee Maria bottle feeding a baby who was born there and the famous iconographic photograph of the young director, Elisabeth Eidenbenz, with a little Spanish girl in her arms. In the aforementioned maternity the destitute pregnant refugee women, many of them brought from internment camps, could give birth irrespective of their nationality or religion. It is estimated that during the Second World War, at least 600 children were born here with good prospects of survival in this oasis of peace surrounded by the barbarism of the war.

The organization and inventiveness in Elne seemed to fascinate him, as can be inferred from the photographs of the new-born babies, distributed in shopping baskets neatly placed in a row in the absence of cots, as well as a vegetable garden and the plantation of apricots, surrounded by cane railings, behind which can be seen the Maternity building, an old abandoned palace reformed by Swiss Aid.

The fruit box option, also replacing the non-existent cots in Banyuls, a nursery annex to the Maternity in Elne, run by nurses Madeleine Durand and Lydia Müller, inspired another visual report by Paul Senn published in the $10^{\text {th }}$ issue of the magazine Sie und $\mathrm{Er}^{11}$ on the $6^{\text {th }}$ of March 1942. In the same report appear images of the pitiful ini- tial condition of two babies and of their striking improvement after receiving a few months' health care from the Swiss humanitarian aid staff. ${ }^{12}$

The photographs in no.9 the SZI magazine of Pringy, another children's reception centre, convey the happiness of the 60 orphans or children of prisoners of war who were able to enjoy the attentive care of director Ruth von Wild who ensured they led a disciplined and regulated life. Their teacher from Basle, Hermann Friess, also fulfilled the role of children's hairdresser, as she showed the photographer.

Part of Paul Senn's activity continued to be linked to Swiss humanitarian aid during and after the Second World War.

\section{SUBLIMINAL MESSAGES THROUGH THE SYMBIOSIS OF TEXT AND IMAGE}

The Zürcher Illustrierte ${ }^{13}$ magazine, for which Senn undertook his documented trips, was a pioneer in offering photographic reports. From 1929 onwards, this weekly magazine had concerned itself with the everyday life and hostilities. Its editor Arnold Kübler surrounded himself with anxious and committed professional photographers, including Paul Senn, Gotthard Schuh ${ }^{14}$ (22/12/1897 Berlin-Schöneberg - 29/12/1969 Küsnacht, Zurich), Hans Staub $^{15}$ (10/09/1894 Wetzikon, Zurich - 27/05/1990 Zollikon) and Ernst Mettler (01/07/1903 St. Gallen 08/11/1933 Zurich), all with some knowledge, apart from photography, of other artistic disciplines, such as graphic art, sculpture and/or painting. They shared an interest in social documentation, both in and beyond Switzerland, subsequently reflected in photo reports. The first three, known in Switzerland as the three "S's", contributed major innovations to photographic journalism in Switzerland from the 1930s onwards. With their help, the journal ZI pioneered an avant-garde movement in photography: it opted for realistic images, relying solely and exclusively upon on camera, paper, light and visual language rather than the usual trend of $19^{\text {th }}$-century retouching and embellishment that eventually gave way to the new criteria. ${ }^{16}$

Paul Senn's experience travelling with the SAS to Valencia and Madrid in 1937 was condensed into a special issue entirely devoted to Spain and the Civil War. In issue No. 25 of the magazine Zürcher Illustrierte, in June 1937, the editor made it clear that its goal was not to the armed conflict itself, but the people who were suffering, appealing to the reader to contemplate the victims with pity in their eyes while also condemning the war.

The magazine was a faithful catalyst of the clearly republican intentions of the SAS, saying that the latter worked alongside the Spanish Government, definitely more affected, and "has no other aim than that of striking at the heart of the reader. ${ }^{17}$ "

The caption comments intensify and channel the sensations experienced by the journalists in situ through the artistic resource of photography.

Although the texts were the responsibility of other journalists, occasionally Paul Senn, apart from his work 
as a photographer, also wrote comments on the articles. His literary style may be defined as moderate because of the absence of sensationalist drama and the specific appeals of the press, giving rise rather to objective prose and consequent reflection, occasionally infused with flashes of cold anger, denouncing not only the cruelty of the war, but also human stupidity, a premise of the latter.

Thanks to the combination of immortalized images and the accompanying texts that lead to the photographic reports, there is intentional and prior selection of the reaction of the public they are aimed at: in this case, compassion for the displaced and refugees, as well as indignation at the war. This strategy, of appealing to a specific feeling within a wide range of possible emotions, skilfully refining artistic resources to this end, reduces the likelihood of potentially opposite reactions in the reader (Sontag, Susan, 2003:21): "Photographs of an atrocity may give rise to opposing responses. A call for peace. A cry for revenge. Or simply the bemused awareness, continually restocked by photographic information, that terrible things happen."

Thus, Paul Senn refused to take photographs of the corpses of 53 children, victims of hypothermia in the "La Retirada", who were buried behind an old hut. ${ }^{18}$ If he had immortalized their lifeless bodies, the reaction of the target group could have been disproportionate, bordering on disgust, repugnance and even rejection.

In order to create empathy, it was necessary to establish proximity between the Swiss reader and those remote countries afflicted by a hostile situation, such as Spain. The photographic reports in the magazines include didactic and descriptive references to Spanish idiosyncrasy, the way of life, the mentality of Iberian citizens and their efforts to survive, but also impressions of the landscapes and other sensations unfamiliar to a Swiss Alpine. At the same time, informative articles were published on the subject of Spanish contemporary history.

In Switzerland the image of romantic, passionate, ungovernable and quixotic Spain prevailed. In fact, several successive articles of the magazine Der Aufstieg ${ }^{19}$ carry the title "Don Quichotte und sein Land" [Don Quixote and his land] and the Global Title of the magazine no.30 (1937) read: "Fern im Süd das schöne Spanien" [Far away in the South of the beautiful Spain] alluding to the title of an 1837 lyric poem by Emanuel Geibel, which fuelled the unrealistic stereotype image of Spain generally held by the Swiss and German population. Given the distance, not only geographic but also cultural, this exotic country evoked fascination and surprise at the same time.

There are plenty of comments based on experience, both by journalists in magazines by and in books by SAS volunteers, sometimes sarcastic, unrelated to the Civil War, such as mention of the careless manner in which vehicles are driven in Spain. On the other hand, positive prejudice was encouraged by the love for children, a characteristic described as Spanish par excellence.

These intentions, objectives and prior aspirations linked to photography pass the final filter of real publicity: magazine circulation, the emphasis of the aid associations on obtaining donations for the refugees, the search for the most dramatic effect to attract the attention of the public without going too far, and finally, and from 1942 onwards, state censorship of the press which sought to conceal the issue of Jewish persecution by the Nazis.

Susan Sontag (2006: 38) considers that the image only reinforces the intention, its "ethical content is fragile" and continues by emphasizing: "Photographs cannot create a moral position, but they can reinforce one [...]." The symbiosis between the image and the text, in this particular case, encourages the said function, while in an isolated way, the photographs would not fulfil their purpose with such effectiveness. The text directs and determines the point of view that the reader has to maintain and that the image reinforces.

What is palpable is what Susan Sontag (2006:42) called additional "violation" by means of photography:

The limit of photographic knowledge of the world is that, while it can goad conscience, it can, finally, never be ethical or political knowledge. The knowledge gained through still photographs will always be some kind of sentimentalism, whether cynical or humanist. It will be a knowledge at bargain prices-a semblance of knowledge, a semblance of wisdom; as the act of taking pictures is a semblance of appropriation, a semblance of rape.

The simulation is identifiable with an illusion, the photographer's illusion projected onto the subject. The same subject, photographed by different portraitists, produces different results, because of the personal backgrounds of the authors of the photos, which in turn are due to personal experiences that generate specific feelings. These particular feelings vibrate on the same wave length before the singular perception of the subject's qualities related to them.

Ethics within photography are also questioned because of the fact that each act of photographing involves a different nuance of "violation" or "theft" by freezing possible feelings and facets of the subject, materializing and collecting them, that is, by freezing a glimpse of their life. The photographic result, in the days of Paul Senn, was certainly not visible to the subject due to the slow process of developing negatives. Could the subject question the photo in the event of disagreement or perhaps prevent its mass publication within an unknown textual context? (Sontag, Susan, 2006: 156). It is very unlikely that the portrayed war victims would see their image published in a magazine in Switzerland.

The photograph interferes with the feelings of the subsequent spectator who may be, in the worst case scenario, victim of manipulation by the photographer, the magazine and even the State propaganda. It would be necessary to consider whether there are true, not idealized photographs.

During the Civil War the Swiss press, in view of the freedom of political positions expressed, occasionally with vehemence, against the insurgents; seemed to enjoy full freedom of expression, a fact that changed during the Second World War. 
The small Swiss state, with a view to its own survival next to the threatening National Socialist neighbour, and surrounded by countries occupied by the latter, submitted the press to a censorship that sought to glorify the labour of the brave humanitarian aid volunteers, to move readers' hearts and to omit the information regarding the real reasons for the misfortune of the victims (Jews) and the origin of the misery in the concentration camps.

Therefore, all of a sudden the magazines modified the heartrending tone in their reports and articles and partially sweetened the images of the humanitarian aid efforts and their centres of activity:

And all these heroic and brave women to whom our land proudly raises its eyes, serve through the country this labour of love in the most beautiful and convenient way. Every day they have naked and hungry misery before their eyes, but they want to do more, still help more. Should not we, those who in the country only know this by hearsay, double our efforts to enable them to do so? ${ }^{20}$

They could not but include a portrait of those fighting heroines, such as the young Elisabeth Eidenbenz, who appears in a highly iconographic photograph, as she posed with a child in her arms like the Virgin Mary and with the following caption:

Elisabeth Eidenbenz, formerly a teacher, is now a midwife, social worker, nanny and director of the Maternity Ward in Elne, an international maternity hospital, where now some 400 children have seen the light of day. Pregnant mothers are taken out of internment camps and receive loving and professional care until labour. Sister Elisabeth is widely popular and is also an advisor to all the mothers who live nearby. Here we see her with a charming Spanish child of whom she has grown very fond. ${ }^{21}$

The aforementioned photograph was not only published in the Swiss magazines, but also made the front page of French newspapers, embodying the benevolent Switzerland along with titles such as "La Suisse, notre amie", but also the brave Swiss woman who goes out of her way to ensure the well-being of the victims in France, risking her life. The photograph, in its iconology, alludes to the Virgin with the Child, but in this case the virgin is Swiss, and the births of children of refugee mothers occur in as hostile an environment as that suffered by Christ, but in France. The Elne Maternity, run by Elisabeth Eidenbenz, corresponds to Bethlehem in its etymological meaning (house or home of bread and meat).

Antonia Schmidlin (1999: 186-187) emphasizes that the protagonists were for once the Swiss women, weak, inoffensive and without power, lacking the right to political vote in their country, who through their philanthropic help, contributed to the excellent reputation of Switzerland in the international arena.

The article corresponding to the portrait of Elisabeth Eidenbenz by Paul Senn in the Swiss magazine begins with Goethe's famous aphorism: "Bist du ein Mensch, so fühle meine No" [If thou art human, feel my misery], a parallelism between victims in need and those imprisoned, like Margarethe, who, from the prison in which she was confined, invokes that sentence from Faustus who had sold his own soul to Mephistopheles (the devil). Once again the goal of this article is to inspire empathy in the Swiss reader for the victims of wars to become a donor and ensure the survival of humanitarian aid and that of the victims.

The global composition of the article in the magazine, deliberately revealing, begins on the first page with the aforementioned quotation from Faust "If you are a human being...", to allow for an effective symbiosis with an equal balance between explanatory texts and images that at the same time document and idealise Swiss Aid's work in France, immortalising the spotless barracks of Rivesaltes, Elisabeth Eidenbenz and a distribution of aid at the Toulouse headquarters.

The next page, headed with the continuation of the initial quotation: "... then feel my misery", features more images harmoniously alternating with texts in which the assisted victims and the volunteer helpers, more numerous than on the previous page, are the protagonists. To this end the photographer had travelled to the centres in Pringy, Elne, and Toulouse.

Swiss patriotism is reflected via the photographs that document the nature of Swiss humanitarian aid in Spain: organized, tidy, clean, inspiring optimism and security for the displaced and refugees by means of a photograph showing a nurse with exotic features, non-Swiss, in an immaculate environment with medical equipment and a Swiss flag in the background, accompanied by the commentary: "Sister Maria, herself a refugee, who is linked to the aid work in Elne from the beginning, feeds the baby the midday cup with [the] good Swiss milk.22

Switzerland's cooperation with National Socialist Germany is omitted, for obvious strategic reasons, and the concealment of the real facts is also employed: the euphemism of "International Maternity" to define the Maternity in Elne is due to the fact that not only Spanish and French refugee mothers were welcomed, but also the Jewish victims of National Socialism who are not mentioned. ${ }^{23}$ ",

However, the layout of the last two pages breaks with the moderation and balance of the previous ones, giving rise to a dramatic effectism resulting from the disproportionate size of the images, to the detriment of the text, in order to underline the final empathetic imperative that no longer recites Goethe outside his usual context, but functions by way of instruction: "... read in their faces." It directs the reader towards the row of undernourished faces of the prisoners photographed in Rivesaltes. The image of these faces, many of them children, dignified by the photojournalist's visual language, is all that is required in order to convey the real situation in the camps and welcome centres, an achievement beyond the written word. The caption below a shocking portrait clearly assigns priority to the image so as to transmit the misery: 
The elderly teacher

Formerly, she was an infant school teacher and only frequented lofty social circles. But the war saw her lose her entire fortune and had to abandon her home in order to survive. Silent and shy, she was sitting in the room for the sick, when our photographer discovered her. We do not have permission to reveal what she told of her life, however - everything is written on her face.

In turn, the text alongside the faded picture of the teacher implies that here are more heart-breaking documents and invites the fortunate Swiss who enjoy safe and prosperous lives to also look at themselves in the mirror.

Given the different circumstances, one can see, in short, that the text and the content of the magazine articles from 1942 onwards differ from those of 1937 and 1939 , not only because of their less partisan tone but also because they avoid compromising issues. There is no accusation against the xenophobic policy vis-à-vis European Jews. The war would become an unpredictable and unforeseeable natural phenomenon, immune to the intrusion of man, similar to the eruption of a volcano. All that is asked for is the contribution of the citizen to alleviate the consequences of the war.

The magazines would thus fulfil the intended function of the State: to show the official, friendly, efficient and altruistic Switzerland, without explicitly mentioning the other side of the coin. In spite of this, the editorial team succeeded in avoiding censorship in this latter article by means of the deliberate stratagems of the ambiguous title, and the alternation between texts and images and certain passages, partly revealing of another silenced reality. Every perceptive reader would have captured the subliminal message expressed between the lines - and images.

\section{VISUAL LANGUAGE IN PAUL SENN'S PHOTOGRAPHY}

A thorough analysis of Paul Senn's photographs means taking into account the anachronism, the experiences and the personal motivations of the photographer, his objective and his style, the concept of Spain prevalent in Switzerland and the filter of advertising.

The current anachronism is primarily physical and sensory due to the oversaturation of images by multiple means of communication. Therefore, the impact of Paul Senn's photographic work is only appreciable with knowledge of the appropriate contextual framework and acquiring a purer consideration of the moment, typical of a Swiss of the thirties, in the absence of television, inebriated with prejudice, excessively romantic and distorted with regard to Spain as provided by the literature of illustrious German-speaking figures. For an audience of these characteristics, the images of the photojournalist, the cherry on the cake of a photographic report, must have caused a considerable impact.

With regard to Paul Senn's personal experiences, his previous empathy with the victims of misfortune of various kinds (maltreatment, confinement in centres, poverty, orphanhood or war) stands out. His portraits, above all, dignify and monumentalize these victims, since they are allegorical in their message. By means of plastic language, the subjects are immortalized; protagonists of the experiences of abandonment, although their name is not reflected in reports. It is not surprising that Senn, of humble origins, opted for the representation of social and political injustice. His goal, apart from covering his basic vital needs, was focused on manifesting his sympathy, his compassion for the persecuted which the reader subsequently experiences when contemplating the photographs. As a serious expert in his profession, he makes the invisible visible. The compositions of Paul Senn's "socially oriented photography" are characterized by their "marked chiaroscuro, accentuated contrasts and their monumentality. ${ }^{24 "}$ Through these tools of plastic language, he achieves proximity and intense compassion for the victims.

Very evident is his respect and love for children in the photographs of the children evacuated at different times of their life during the war, especially the psychological portraits of minors confined in the Rivesaltes concentration camp, experience that robbed them of their childhood, fact captured in the photographs showing their faces of adults before their time.

Man is immortalized in his diverse facets: self-confident warrior, optimist despite his wounds, the Spanish family man with a hardened face, but also the worn old man, with no present and no future and those who return to Switzerland, young people of the International Brigades, without victories or recognition.

His photography expresses his admiration for art and creative artists, among them Pablo Casals and Aristide Maillol.

And justice cannot be done to Paul Senn without mentioning his pictures of urban landscapes in which the human being is never missing, whether in Madrid, besieged by war or in "La Retirada" via Le Perthus or in Switzerland itself.

Paul Senn's pictures transcend mere sensationalism. Yes, there are pictures of corpses and those who died in the war, but their images not only reflect the pathetic surface. They are the product of an inner reading and the understanding of the motive or subject, which is materialized through photographic technique and the application of highly reasoned artistic language, especially that of hierarchy within the photographic composition. For this reason, their images compensate for the absence of spontaneity, especially visible in the static portraits that seem to be the product of a "previous arrangement" of the photographer, with the depth of emotions that they contain.

In the refuge on García de Paredes Street, the photographer immortalized The Mother, visible in Figure 1, representative of the tragedy of the civilian victims of the war, homeless, separated from her children, one of whom had died. Senn barely dared to photograph her, due to her absorbed attitude, with no interest in her surroundings. In the caption he notes: 
At one of the tables of the "Refugio García de Paredes" for the homeless, she was sitting in Madrid with hundreds of others, her wrinkled skin yellow as leather, the whites of her black eyes brightly shining from her face. The hands are folded, lonely, deeply mournful. Her house is destroyed, the children are fleeing, one is dead. From the purse she carries, she takes out the splinter of bullet that had killed him. 'Look, his blood!' pointing at the dark marks in the fissure of the piece of metal. ${ }^{25}$

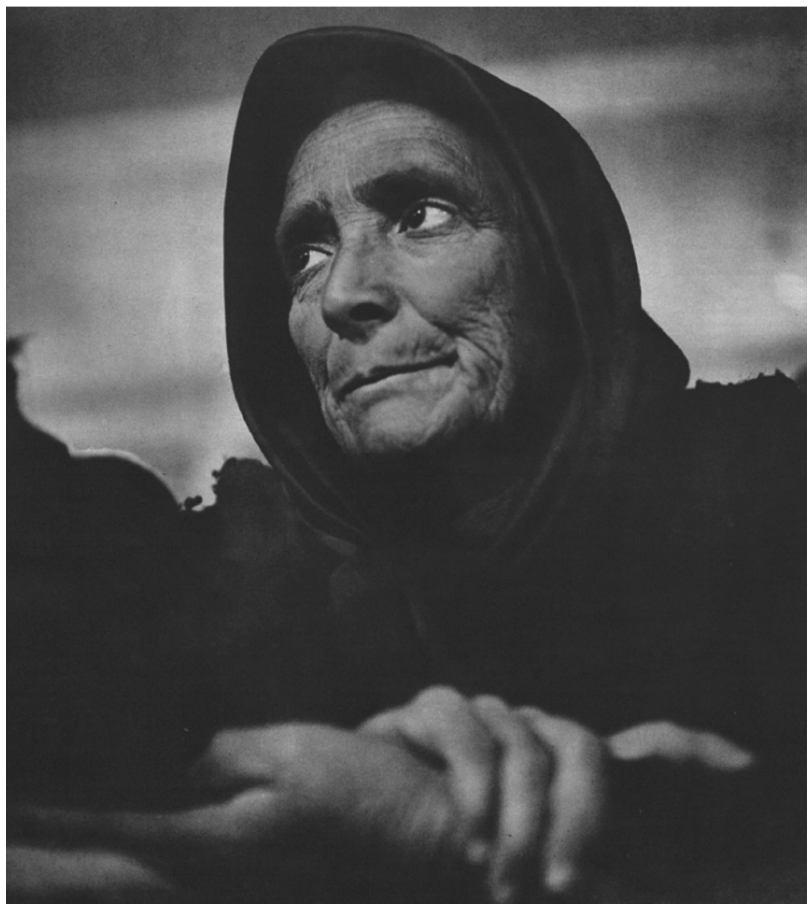

FIGURE 1

Source: Bernische Stiftung für Fotografie, Film und Video,

Kunstmuseum Bern, Depositum Gottfried Keller-Stiftung. (C) Gottfried Keller-Stiftung, Bern. Signatur Digitalisat: PS_X999_115NEND001R. ID Foto: 15785. Alte Flüchtlingsfrau, Spanien, 1938.

Above all, the low angle stands out, that is, the portrait of the person "from low down" which in this case provides the monumentality that Paul Senn confers upon several characters in his photographic work. This perspective is often used to represent strong people and those with power. Monarchs and high dignitaries made use of the same effect by sitting on a raised pedestal, indicative of a rank superior to that of the common people.

With regard the hierarchy of the composition, the predominant element towards which the photographer guides the spectator's gaze are the subject's eyes, because here is where the greatest brightness and contrast of chiaroscuros is to be found, although the look is averted. The face is framed by the ovoid shape drawn by the handkerchief and which also accentuates the physiognomy. With the same aim of not detracting from the face, against all perceptive logic, the photographer has blurred the hands in the foreground. Neither did he attach importance to the background of the photograph, which is why it is blurred.

\section{CONCLUSION}

Paul Senn's photographic activity in Spain and the South of France during the Civil War and the Second World War was closely linked to Swiss Relief's humanitarian work. His monumental photographs, more reasoned in their artistic language than spontaneous, contain his own empathy with the victims and connected with the reader and the viewer, making them potential donors, necessary for the survival of philanthropic actions in favour of women and children in distress during times of war, due to the author's own humble origins. The photos were faithful products of the new technically purist photographic style of 1930 s Switzerland, which placed the emphasis on the representation of everyday life at home and abroad rather than the traditional sentimental photography now regarded as obsolete and unreal. The images were part of the then novel photographic reports, a symbiosis between text and image, which aspired to transmit information about a Spain torn apart by the Civil War, the labour of the Swiss Relief in Spain and later the fate of the Spanish and Jewish refugees in the South of France. From 1942 onwards, due to press censorship, the message of photojournalism was modified. It focused on the heroism of volunteer helpers and the representation of victims in reception centres, but without insisting on the origins and causes of their misfortunes. Nor were certain photos published documenting the misery of the Rivesaltes concentration camp, following this state policy of selective concealment.

These circumstances did not prevent SIZ magazine from escaping censorship, opting for innovative methods whereby the image, in its visual and artistic essence, acquired a primordial condition, since the latter, non-verbal in nature, appealed to the reader's perception. To this end, photographer Paul Senn contributed images that remained within the realm of the acceptable in terms of their narrative content, but via particular visual resources transmitted additional information about the genuinely precarious situation of the victims in the south of France. The images connected with readers and spectators, turning them into potential donors, so necessary for the survival of the philanthropic actions in favour of vulnerable women and children during times of war. In this way a twofold function was fulfilled: raise funds for Swiss Aid and at the same time raise readers' awareness of hidden realities vis-à-vis the nature of war. They were thus invited to question the neutral role of the Swiss state during these conflicts, and the existence of censorship of the press was hinted at.

\section{ACKNOWLEDGEMENTS}

I thank Markus Schürp, director of the Kunstmuseum Bern, for providing the information and the photographs of Paul Senn, and to Alicia Alted, Rose Duroux, Sabina Gau, and Miguel Ángel Martín for the theoretical knowledge, comments and suggestions made. 
This article is part of the project "European Humanitarian Aid in France during the Second World War". Ref.: HAR2014-58043-P, Ministerio de Economía y Competitividad, Gobierno de España.

\section{NOTES}

1 http://www.swissinfo.ch/ger/paul-senn--die-ikone-derschweizer-fotoreportage/5968936

[Accessed May 10, 2016]

2 This is a Swiss state mediation project from 1800 to the 1980 s for children from unstructured families, single mothers, gypsies, orphanages or with some physical or mental disability who were distributed by the Swiss authorities to peasants or other host families in exchange for a modest pension for supporting them. A great majority of these children were exploited and mistreated without the intervention of the state in this example of modernday slavery, a fact expressed in the term "Verdingkinder" [approximate translation by the author: "Objectified children"].

3 Peter Surava (1912-1995). He is the Swiss journalist Hans Werner Hirsch who operated under the pseudonym of Peter Surava. Both his training as a graphic designer and his work experience in a youth hostel served as a benchmark for his journalistic work begun in 1939. As editor he made Die Nation magazine a success. His articles, critical of German National Socialism and Swiss official policy, brought him into conflict with official censorship, and his social reports illustrated with Paul Senn's photographs were innovative. He continued working on the writing of the Vorwärts magazines, of the communist regime, Grüner Heinrich, of satirical character. After retiring from public life due to criminal judicial proceedings, he continued to publish, under different pseudonyms, books and articles of varied subject matter, culminating with his autobiography under the title "Er nannte Sich S." which gave rise to the documentary film in 1995 by Erich Schmid under the same title, after which he won different tributes and awards, including the Nanny-andErich-Frischhof award.

Historisches Lexikon der Schweiz: http://www.hls-dhs-dss.ch/ textes/d/D41626.php [Accessed December 16, 2017].

4 Swiss humanitarian aid for Spain had its beginnings with the SAS "Spanische Arbeitsgemeinschaft für Spanienkinder", in existence from 1937 to 1939 , which was the result of the fusion of 13 non-state Swiss suborganizations, of diverse philosophy and religious confession, but united in the purpose of providing assistance to the Spanish civilian population affected by the Civil War through evacuation from the areas being bombed, distribution of food imported from Switzerland and installation of canteens and dining halls. The start of the Second World War, German National Socialist policy and the consistent wave of refugees in distress required an extension of humanitarian aid with respect to its geographical radius of action. The SAS was extended with 6 additional sub-organizations and in 1939 became the SAK "Schweizerische Arbeitsgemeinschaft für Kriegsgeschädigte Kinder" [The Swiss Aid Association for Child War Victims] operational until the end of 1941. In 1942 the SAK underwent, through the merger with Swiss Red Cross, some notable changes in its ideology and humanitarian action, becoming SRK-Kh "Schweizerisches Rotes Kreuz, Kinderhilfe." [Swiss Red Cross, Aid to Children] and remained in operation until the end of 1943. In 1944 the organization Schweizer Spende (Don Suisse) was already established, with a distinct purpose: engagement in the reconstruction of Europe.

5 Senn, Paul (1938) "Fliegerangriff auf Valencia", Der Aufstieg, 29: 661 .

6 Senn, Paul (1937) "Blick auf Spanien", Zürcher Illustrierte [ZI], 25: 771 .

7 Senn, Paul (1939) "Was ich gesehen habe", Der Aufstieg, 8: 180.

8 Senn, Paul (1939) "Nach Frankreich!”, [ZI], 6: 146.

9 SCI Archives (SCI), SCI - 2036.4, von WILD, Ruth: Flucht aus Katalonien, February 9, 1939.
10 Senn, Paul (1939) "Nach Frankreich!”, [ZI], 6: 147.

11 The Swiss weekly illustrated magazine Sie und Er, edited by Ringier, existed from 1929 to 1971 .

12 These may possibly not be photographs taken by Paul Senn, but by the nurses themselves, due to the time frame between the first and last photograph of each of the two children.

13 The weekly magazine, Zürcher Illustrierte, dedicated exclusively to culture and sport, was founded by the publishing house Conzett \& Huber in 1925. From 1929, thanks to Arnold Kübler who lead the editing, the photographic report was introduced that documented general daily life, equating on the one hand artistic demands with cultural demands. In the interwar period it was one of the most enlightened magazines that defended the interests of victims of unfair situations. In 1941 the economic demands of the market prevailed, and it was purchased by a competitor, the Ringier Verlag, which ceased its publication. Historisches Lexikon der Schweiz: http:/www.hls-dhs-dss.ch/ textes/d/D49596.php [Accessed December 16, 2017].

14 Gotthard Schuh, after working as a painter in Munich, moved onto photography from 1928 onwards with the very personal visual style he acquired in Paris, known as poetic realism. From 1931 to 1941 he worked as a photojournalist for ZI, also publishing for foreign magazines. Photographic journalism marked his life, with the landmarks of an extensive report on his trips to Singapore, Java, Sumatra and Bali and his position as chief picture editor at the Neue Zürcher Zeitung (NZZ) from 1941-1960. His subject, the poetics of everyday life, reflects the avant-garde photographic movements of the 1930s. He was aware of the power of the photographer's subjective stamp upon his images, hence his interest in visual psychology and the intuitive element. https://www.fotostiftung.ch/ausstellungen/ausstellungsarchiv/ gotthard-schuh/ [consulted 16/January/2019].

Historisches Lexikon der Schweiz: http://www.hls-dhs-dss.ch/ textes/d/D27231.php [consulted 16/January/2019]

15 Hans Staub, after various spells during his life as an agricultural volunteer, his time in Schools of Industry (Wetzikon) and of Agriculture (Zúrich) and training as as sculptor, finally began his career as a photographer and joined ZI as its first photographic journalist, as well as working as a war correspondent and for other journals. Prominent among his extensive work of a social nature are his documentary images of Second World War prisoners and refugees for the Red Cross. His work seeks to immortalise life in the streets, unemployment, children, the elderly, but also celebrities.

Historisches Lexikon der Schweiz: http://www.hls-dhs-dss.ch/ textes/d/D27234.php [consulted 16/January/2019].

16 The controversy between traditional photography and the new realism materialised at two contrasting travelling photography exhibitions: in 1932 a display of innovative photography that passed through Berne, Aarau, Lausanne, La Chaux-de-Fonds, Basle, Lucerne, Winterthur and Zurich organised by the Schweizerische Werkbund (SWB) as a protest against the first exhibition of artistic photography in Lucerne intended to pay tribute to photographers regarded as backward and artificial. https://www.fotostiftung.ch/ausstellungen/ausstellungsarchiv/ bilderstreit/ [consulted 16/January/2019].

17 Senn, Paul (1937) "Blick auf Spanien", [ZI], 25: 770.

18 Senn, Paul (1939) "Was ich gesehen habe", Der Aufstieg, 8: 180-181.

19 The weekly magazine Der Aufstieg of Berne, considered a family illustrated magazine of socialist leanings, active from 1920 to 1980, followed the evolution of the Spanish Civil War by publishing articles on behalf of Central Swiss Humanitarian Aid and its sub-organizations such as the Basler Samariterhilfe [Basel Samaritan Aid], the Vereinigung der Freunde des republikanischen Spanien [Union of Friends of Republican Spain], the Hilfsgesellschaft für das Schweizer Sanatorium [Aid Society for the Swiss Sanatorium], the Sanitätshilfe der Centrale Sanitaire [The Sanity Aid of the Central Sanitaire], etc.

20 Senn, Paul (1942) "Bist du ein Mensch... so fühle meine Not. Lest in Gesichtern! Ein Bildbericht von der Tätigkeit des schweizerischen Hilfswerks in südfranzösischen Kinderheimen 
und Flüchtlingslagern”, Schweizer Illustrierte Zeitung [SIZ], 9 : 261-265.

21 Senn, Paul (1942) "Bist du ein Mensch... so fühle meine Not Lest in Gesichtern! Ein Bildbericht von der Tätigkeit des schweizerischen Hilfswerks in südfranzösischen Kinderheimen und Flüchtlingslagern", [SIZ], 9: 261-265.

22 Senn, Paul (1942) "Bist du ein Mensch... so fühle meine Not. Lest in Gesichtern! Ein Bildbericht von der Tätigkeit des schweizerischen Hilfswerks in südfranzösischen Kinderheimen und Flüchtlingslagern", [SIZ], 9: 261-265.

23 Of nearly 600 registered births there, it is estimated that 200 of them were Jews. Check online: http://www.srf.ch/play/tv/srfwissen/video/ein-herz-fuer-kinder--schweizer-retterin-imzweiten-weltkrieg?id=344f69e5-9e67-49e2-af1 c-6279ba2dd6a 1 [Accessed June 3, 2016].
24 Historisches Lexikon der Schweiz: http://www.hls-dhs-dss.ch/ textes/d/D27233.php [Accessed May 10, 2016].

25 Senn, Paul (1937) "Die belagerte Hauptstadt", [ZI], 25: 794.

\section{REFERENCES}

Olgiati, Rodolfo (1944) Nicht in Spanien hat's begonnen. Herbert Lang \& Cie Verlag, Bern.

Schmidlin, Antonia (1999) Eine andere Schweiz. Chronos Verlag, Zürich.

Sontag, Susan (2003) Ante el dolor de lo demás. Aguilar, Altea Taurus, Alfaguara, S.A., Buenos Aires.

Sontag, Susan (2006) Sobre la fotografia. Santillana Ediciones Generales, S.A. de C.V., México. 